\title{
Can Dosing Unit
}

National Cancer Institute

\section{Source}

National Cancer Institute. Can Dosing Unit. NCI Thesaurus. Code C48479.

A dosing unit equal to the amount of active ing redient(s) contained in a can. 